\title{
Freezing goat embryos at different developmental stages and quality using ethylene glycol and a slow cooling rate
}

\author{
[Congelação de embriões caprinos em diferentes estádios de desenvolvimento e qualidade utilizando \\ etileno glicol e taxa de resfriamento lenta]
}

\author{
J.F. Fonseca ${ }^{1}$, R.I.T.P. Batista ${ }^{2}$, J.M.G. Souza-Fabjan ${ }^{2}$, M.E.F. Oliveira ${ }^{3}$, F.Z. Brandão ${ }^{2}$, J.H.M. Viana ${ }^{4}$ \\ ${ }^{1}$ Embrapa Caprinos e Ovinos, Núcleo Regional Sudeste - Coronel Pacheco, MG \\ ${ }^{2}$ Universidade Federal Fluminense - Niterói, RJ \\ ${ }^{3}$ Universidade Estadual Paulista - Jaboticabal, SP \\ ${ }^{4}$ Embrapa Recursos Genéticos e Biotecnologia - Brasília, DF
}

\begin{abstract}
The efficiency of an alternative freezing protocol for goat embryos of different morphology and quality was tested. Fifty-eight embryos on Day 6-7 stage were transferred as fresh or after freeze-thawing ( $\mathrm{n}=29$ /group). For freezing, embryos were placed into $1.5 \mathrm{M}$ ethylene-glycol solution for 10min. During this time, they were loaded in the central part of $0.25 \mathrm{~mL}$ straw, separated by air bubble from columns containing PBS/BSA $0.4 \%$ plus $20 \%$ BFS. Straws were then frozen using a freezing machine from $20^{\circ} \mathrm{C}$ to $-6^{\circ} \mathrm{C}$ at a cooling rate of $3^{\circ} \mathrm{C} / \mathrm{min}$, stabilization for $15 \mathrm{~min}$ (seeding after $5 \mathrm{~min}$ ), from $-6 \mathrm{C}$ to $-32^{\circ} \mathrm{C}$ at $0.6 \mathrm{C} / \mathrm{min}$, and plunged into liquid nitrogen. Frozen embryos were thawed for $30 \mathrm{~s}$ at $37^{\circ} \mathrm{C}$ in a water bath. Embryos subjected to fresh transfer were maintained in holding medium $\left(37^{\circ} \mathrm{C}\right)$. Fresh and frozen-thawed embryos were transferred at day 7 post-estrus to 30 recipients. Kidding and kid born rates were similar (P> 0.05), respectively, for recipients receiving fresh $(66.7 \%$ or $10 / 15 ; 55.2 \%$ or $16 / 29)$ or frozen-thawed (60\% or $9 / 15 ; 51.7 \%$ or $15 / 29)$ embryos. The cryopreservation of goat embryos using slow-freezing protocol and 1.5MEG resulted in similar efficiency rates of fresh embryos.
\end{abstract}

Keywords: embryo survival, embryo transfer, goat, slow freezing

\section{RESUMO}

Este estudo testou a eficiência de protocolo alternativo de criopreservação de embriōes caprinos de diferentes qualidades morfológicas. Foram utilizados 58 embriões, coletados entre o sexto e o sétimo dia do ciclo estral ( $n=29 /$ grupo). Embriões congelados passaram por solução 1,5M etilenoglicol por 10min e foram aspirados durante esse tempo para parte central de palheta $0,25 \mathrm{~mL}$, separada por bolhas de ar de colunas contendo PBS 0,4\% BSA e 20\% SFB. As palhetas foram congeladas em máquina de congelação de $20^{\circ} \mathrm{C}$ a $-6^{\circ} \mathrm{C}$, com taxa de resfriamento de $3^{\circ} \mathrm{C} / \mathrm{min}$, estabilização por $15 \mathrm{~min}$ (seeding após $5 \mathrm{~min}$ ), $-6^{\circ} \mathrm{C}$ a $-32^{\circ} \mathrm{C}$ a $0,6^{\circ} \mathrm{C} / \mathrm{min}$, e imersas em nitrogênio líquido. Os embriões foram descongelados por $30 \mathrm{~s}$ a $37^{\circ} \mathrm{C}$, em água. Embriōes frescos foram mantidos em solução de manutenção $\left(37^{\circ} \mathrm{C}\right)$. Embriōes frescos e congelados/descongelados foram transferidos para 30 receptoras no sétimo dia do ciclo estral. A taxa de partos e a de crias nascidas (respectivamente) foram similares $(P>0,05)$ para receptoras recebendo embriões frescos (66,7\% ou 10/15; 55,2\% ou 16/29) ou congelados/descongelados (60,0\% ou 9/15; $51,7 \%$ ou 15/29). O protocolo de criopreservação de embriões utilizado no presente estudo resultou em índices de eficiência semelhantes aos de embriões frescos.

Palavras-chave: caprinos, sobrevivência embrionária, taxa de resfriamento lenta, transferência de embriões

Recebido em 20 de julho de 2017

Aceito em 16 de dezembro de 2017

E-mail: jeferson.fonseca@embrapa.br 


\section{INTRODUCTION}

The population of domestic goats has grown intensively in the past decade, particularly in developing countries (Aziz, 2010). In Brazil, the production of goat milk and meat has expanded from the traditional areas, such as Northeast, to other regions. The Brazilian Southeast has become the most important region for milk production from specialized goat breeds, such as Saanen, Alpine and Toggenburg. Goats from this region have increased their genetic merit because of a progeny test program - CapraGene (Facó et al., 2011). These dairy herds are reaching significant ranks of milk production (Lôbo et al., 2017), possibly the most productive dairy goat managed under tropical conditions worldwide. Therefore, tropical countries have manifested interest in Brazilian dairy goats and embryos are possibly the main method of genetic material exchange.

Although successful goat embryo transfer has been reported in Brazil more than three decades ago (Jaume and Bruschi, 1985), only in the last decade, the demand for the development of embryo technologies, including embryo cryopreservation, have been increased possibly in function of the expansion of goat production systems. The first reports on successful embryo cryopreservation were published by Whittingham (1971), Whittingham et al. (1972) and Wilmut (1972), more than two decades after Polge et al. (1949) reported the success of freezing spermatozoa. Since then, the techniques and protocols have been modified to optimize cryopreservation of embryos from most species, and at different stages of development, as well as more sensitive embryos, such as those produced in vitro, cloned, or biopsied (Guignot et al., 2006). The most widely cryopreservation technology used commercially is the slow freezing method, which was designed to use cryoprotectants at low concentration (1-1.5M), whereas the strategy of the vitrification method is a rapid solidification of liquid with high concentrations of cryoprotectants (6-7.5M), avoiding ice crystal formation (Fonseca et al., 2001).

In goats, Bilton and Moore (1976) reported the first successful cryopreservation of embryos using the slow freezing method. Subsequently, the majority of goat embryos were cryopreserved by slow freezing with embryo survival rates ranging from $27 \%$ to $59 \%$, considering only excellent and good quality embryos (Rao et al., 1983; Baril et al., 1989; Rong et al., 1989; Holm et al., 1990; Puls-Kleingeld et al., 1992). However, there are few data available of the results of cryopreservation by slow freezing and transfer of frozen-thawed goat embryos with regular quality. Currently, to improve the survival rate of embryos derived in vivo, the most common approach to deal with the disappointing results of cryopreservation is to propose alternatives on the cryopreservation procedures, such as the concentration and type of cryoprotectants, the time and temperature of the protocol, and the addition of additives.

The objective of this study was to investigate the efficiency of freezing goat embryos of different developmental stages and morphological quality using ethylene glycol and a slow cooling rate.

\section{MATERIAL AND METHODS}

This study was carried out in Coronel Pacheco, Minas Gerais State, Southeast region of Brazil. The research unit is located at $435 \mathrm{~m}$ altitude and $21^{\circ} 35^{\prime} \mathrm{S}$ and $43^{\circ} 15^{\prime} \mathrm{W}$. The area has an average annual precipitation of $1,581 \mathrm{~mm}^{3}$ and an average annual temperature of $21 \mathrm{C}$. This research was reviewed and approved by the Comitê de Ética em Uso de Animais da Universidade Federal Fluminense (protocol\# 0116-2011) and it is under the ethical principles of SBCAL (Sociedade Brasileira de Ciência de Animais de Laboratório).

Embryos were recovered from five lactating donors of the Saanen breed, which have produced more than $1,800 \mathrm{~kg}$ of milk during the previous lactation, 3 to 4 years-old, presented 50 to $80 \mathrm{~kg}$ body weight, 3 to 4 body condition score ( 1 to 5 scale) and 180 to 210 days of lactation, with an average daily milk production of 4 to $6 \mathrm{~L}$. An intravaginal device containing $0.3 \mathrm{~g}$ progesterone (Eazi-Breed CIDR ${ }^{\circledR}$, Pfizer Animal Health, São Paulo, Brazil) was inserted (Day 0) and removed six days later. A dose of $22.5 \mu \mathrm{g} \mathrm{d}-$ cloprostenol (Prolise ${ }^{\circledR}$, Tecnopec, São Paulo, Brazil) was injected laterovulvar (Day 0). Superovulatory treatment started $24 \mathrm{~h}$ before CIDR removal with six decreasing doses of pFSH (5IU FSH/kg body weight; Pluset ${ }^{\circledR}$, Laboratórios Calier do Brazil), which were given 
at $12 \mathrm{~h}$ interval (25-25-15-15-10-10\%) (Fonseca et al., 2013). Goats were naturally mated by a fertile buck while in estrus. The first goats mated by a buck in the morning were the last mated in the afternoon. Goats also received three consecutive doses of $50 \mathrm{mg}$ flunixin-meglumine (Banamine ${ }^{\circledR}$, Schering Plough, São Paulo, Brazil) from three to five days after estrus onset to prevent premature regression of corpora lutea (Fonseca et al., 2013). To promote cervical dilation, a dose of $22.5 \mu \mathrm{g}$ d-cloprostenol was given $16 \mathrm{~h}$ before cervical transposing attempt (Pereira et al., 1998) for non-surgical embryo recovered (seven days after estrus) as described by Fonseca et al. (2013). Recovered embryos were classified based on the morphological criteria as the guidelines of the International Embryo Transfer Society (Stringfellow and Seidel, 1999). Half of the embryos was frozen and transferred two days after, while the other half was transferred as fresh. For the fresh embryos transfer, the time elapsed between embryo recovery and transfer did not exceed eight hours. Before cryopreservation or transfer, embryos were maintained in holding medium (Holding Plus Vigro ${ }^{\mathrm{TM}}$, Bioniche, Pulman, USA) at $37^{\circ} \mathrm{C}$.

The embryos to be frozen were exposed to $1.5 \mathrm{M}$ ethylene glycol in PBS supplemented with BSA $(0.4 \%)$ in one-step for $10 \mathrm{~min}$. During this time, embryos were loaded in the central part of the $0.25 \mathrm{~mL}$ straws, separated by air bubble from columns containing PBS/BSA $0.4 \%$ plus $20 \%$ bovine fetal serum (Figure 1). Straws were frozen using a freezing machine (Freeze Control CL $5500^{\circledR}$, Cryologic, Victoria, Australia), using the following protocol: from $20^{\circ} \mathrm{C}$ to $-6^{\circ} \mathrm{C}$ at a cooling rate of $3 \mathrm{C} / \mathrm{min}$, stabilization for $15 \mathrm{~min}$ (seeding after $5 \mathrm{~min}$ ), from $-6^{\circ} \mathrm{C}$ to $-32^{\circ} \mathrm{C}$ at $0.6^{\circ} \mathrm{C} / \mathrm{min}$, and plunged into liquid nitrogen. Embryos allocated to fresh embryo transfer were loaded immediately before transfer similarly to frozen-thawed embryos to the central column of the straw (three columns) but with no cryoprotectant.

(A)

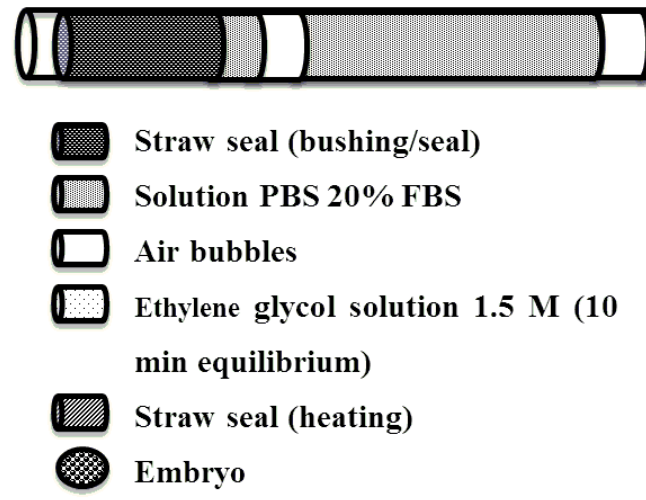

(B)

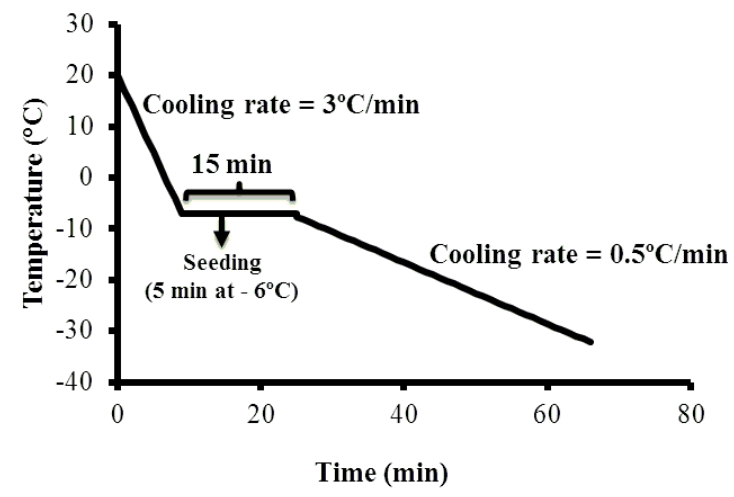

Figure 1. (A) Straw showing different compartments with Phosphate Based Solution (PBS) plus fetal bovine serum (FBS) and ethylene glycol (EG) solution with or without embryo. (B) Slow freezing protocol for cryopreservation of goat embryos used 1.5M EG.

Estrus was induced using hCG as gonadotropin (Fonseca et al., 2005) in 40 recipient goats. Goats received intravaginal devices containing progesterone $\left(\mathrm{CIDR}^{\circledR}\right.$ ) inserted (Day 0) and removed six days later (Day 6) plus $22.5 \mu \mathrm{g}$ cloprostenol latero-vulvar (Day 0) and 250IU hCG i.m. (Vetecor ${ }^{\circledR}$, Laboratórios Calier do Brazil) 24h before CIDR removal (Day 5). Estrus was monitored twice daily with help of teaser bucks. Embryos were transferred seven days after estrus onset into the uterine horn ipsilateral to the corpus luteum using the semi-laparoscopy technique. Recipients were restricted from water and food $24 \mathrm{~h}$ before embryo transfer and received similar epidural anesthesia and sedation protocol as used for donor goats (Fonseca et al., 
2013) plus incisional infusion of $2 \mathrm{~mL}$ lidocaine $2 \%$ without epinephrine $\left(\right.$ Lidovet $^{\circledR}$, Bravet, Rio de Janeiro, Brazil) in the site of $5 \mathrm{~mm}$ trocar insertions. Frozen-thawed embryos were transferred to 15 recipients as single $(n=1)$ or two $(n=14)$ while other 15 recipients received fresh embryos as single $(n=3), 2(n=9)$ or $3(n=2)$. Only embryos with the same morphological characteristics were transferred as twins or triplets. For thawing, straws with frozen embryos were immersed into water bath at $37^{\circ} \mathrm{C}$ for $30 \mathrm{~s}$ and then taken out and dried with a paper towel. After that, straws were handled moved to allow columns content mixture and prompt rehydration. After the choice of the target uterine horn (based in corpora lutea identification by laparoscopy), its cranial portion was clipped and exteriorized by means of non-traumatic forceps toward a trocar orifice. The technique of straw preparation for embryo transfer is illustrated in Figure 2. Straws of frozen-thawed and fresh embryos were dried by towel paper, cut at the heating seal side and coupled to sterile 0 to $20 \mu \mathrm{L}$ tip (transparent tip). This conjunct was used to perforate the uterus. A sterile 50 to $200 \mu \mathrm{L}$ tip (yellow tip) was cut at caudal edge allowing coupling to an insulin syringe with plunger positioned in $0.3 \mathrm{~mL}$ (air containing). After uterine hall perforation, the other side of straw (bushing seal) was cut and coupled to the syringe / 50 to $200 \mu \mathrm{L}$ tip conjunct; the syringe plunger was pressed to release straw liquid with embryos into uterine lumen. Uterine horn is pressed to return to abdominal cavity and antiseptic tetracycline-based spray (Terracortril ${ }^{\circledR}$, Zoetis Animal Health, São Paulo Brazil) was instilled in trocar incisions and no suture was done.

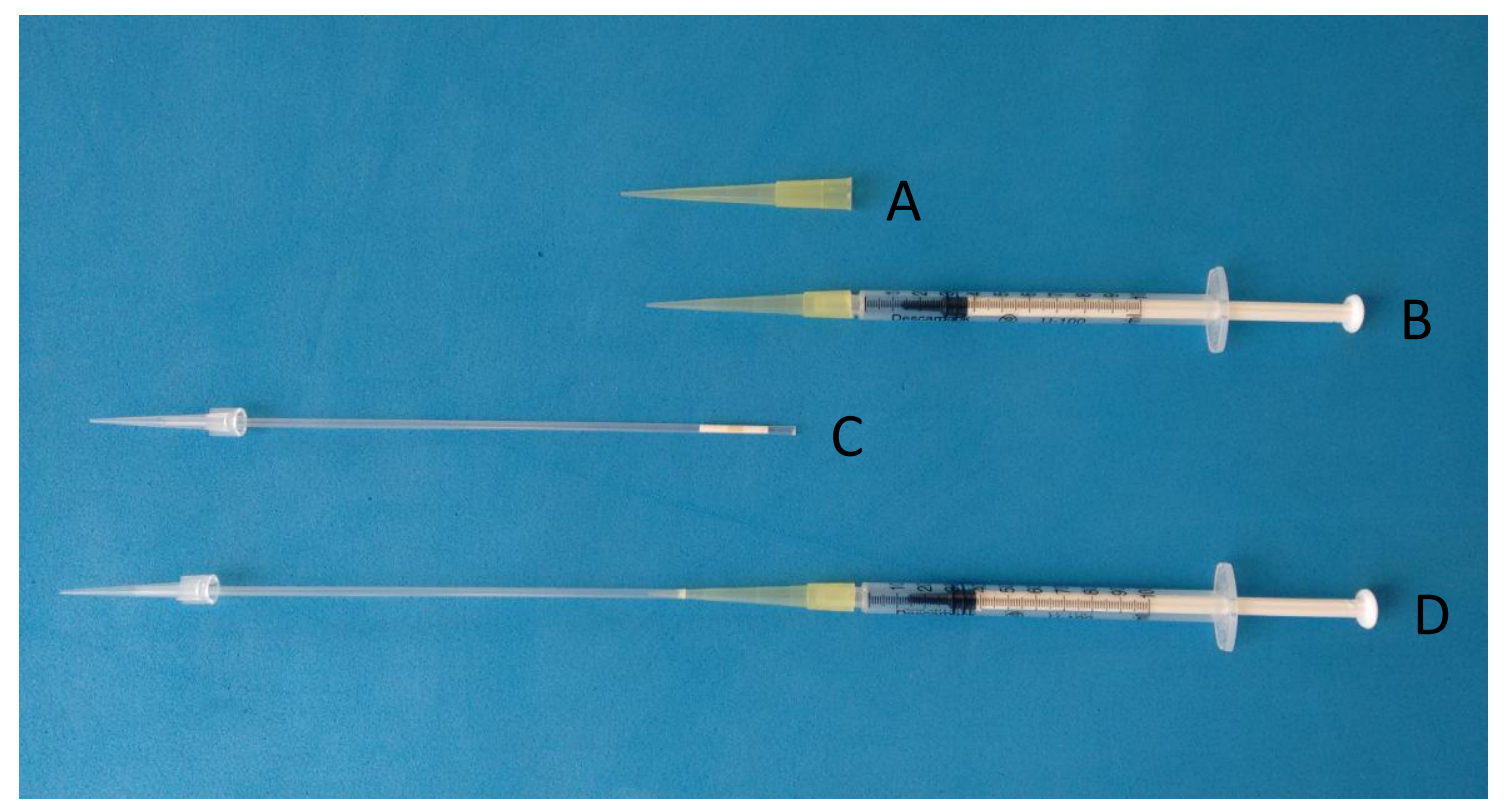

Figure 2. Proposed system to perform embryo deposition into the uterine horn in goats. A - Intact 50 to $200 \mu \mathrm{L}$ tip (yellow tip), B -50 to $200 \mu \mathrm{L}$ tip cut and couplet to syringe with plunger positioned in $0.3 \mathrm{~mL}$ (air containing); C - French straw cut at the heating seal side and coupled to sterile 0 to $20 \mu \mathrm{L}$ tip (transparent tip); D - Complete conjunct ready to release straw content. See the text to details.

Pregnancy was checked at 33 days after embryo transfer by transrectal ultrasonography, using a linear $5 \mathrm{MHz}$ probe $\left(\right.$ Aloka $^{\circledR}$ SSD 500, Tokyo, Japan) coupled to a polyethylene support. The kidding rate was defined as the ratio between the number of goats kidding and the number of recipients that received embryos, and the embryo survival rate was defined as the ratio between the number of kids born and the number of transferred embryos.

Statistical analysis comprised the comparison between fresh and frozen-thawed embryos transferred, according to developmental stage and morphological quality. In the absence of difference for any specific effect, data were pooled, and the embryo survival rates were 
compared for the other effects. Differences were determined using the Chi-squared test. A P-value of 0.05 was considered as significant. Statistical analysis was performed using Prism 5.0 a software.

\section{RESULTS}

No pregnancy loss occurred from ultrasonography diagnosis to parturition. Kidding rates were similar $(\mathrm{P}>0.05)$ between recipients receiving fresh $(66.7 \%$ or $10 / 15)$ or frozenthawed $(60.0 \%$ or $9 / 15)$ embryos. Survival rates expressed as kids born according to embryo developmental stage are shown in Table 1. Embryos were grouped as earlier (compact morulae and early blastocyst) versus advanced stages of development (blastocyst, expanded blastocyst and hatched blastocysts). Kidding rate was higher $(\mathrm{P}<0.05)$ for advanced (73.1\%, 19/26) than for earlier $(37.5 \%$; 12/32) stages, regardless if fresh or cryopreserved embryos.

Table 1. Rate of kids born (\%) after transfer of fresh or frozen/thawed goat embryos to estrous synchronized recipients according to stage of embryo development

\begin{tabular}{ccc}
\hline Embryonic stage & Fresh & Frozen / Thawed \\
\hline Earlier embryos $^{1}$ & $36.8(7 / 19)$ & $38.5(5 / 13)$ \\
Advanced embryos $^{2}$ & $90.0(9 / 10)$ & $62.5(10 / 16)$ \\
Total & $55.2(16 / 29)$ & $51.7(15 / 29)$ \\
\hline
\end{tabular}

${ }^{1}$ Compact morulae $-\mathrm{Mc}$ and young blastocyst $-\mathrm{Bi}$.

${ }^{2}$ Blastocyst $-\mathrm{Bl}$, expanded blastocyst $-\mathrm{Bx}$ and hatched blastocyst $-\mathrm{Be}$.

( ) Number of kids born / number of embryos transferred (Chi-Square test; P> 0.05).

The embryo survival rates according to embryo quality are shown in Table 2. Considering only grade 1 to 2 embryos, $61 \%$ of fresh (14/23) and $62 \%$ of frozen-thawed embryos (13/21) resulted in kids born $(\mathrm{P}>0.05)$.

Table 2. Rates of kids born (\%) after transfer of fresh or frozen/thawed goat embryos to estrous synchronized recipients goats according to embryo quality

\begin{tabular}{cccc}
\multicolumn{3}{c}{ Embryonic quality } \\
\hline Type of embryos & Grade 1 & Grade 2 & Grade 3 \\
Fresh & $64.7(11 / 17)$ & $50.0(3 / 6)$ & $25.0(2 / 6)$ \\
Frozen-thawed & $53.8(7 / 13)$ & $75.0(6 / 8)$ & $25.0(2 / 8)$ \\
Total & $60.0^{\mathrm{a}}(18 / 30)$ & $64.3^{\mathrm{a}}(9 / 14)$ & $28.6^{\mathrm{b}}(4 / 14)$ \\
\hline
\end{tabular}

( ) Number of kids born / number of embryos transferred.

${ }^{a, b}$ Numbers with different superscripts in the same line differed (Chi-Square, $\mathrm{P}<0.06$ ).

One recipient that received three fresh Mo-3 morulae had two kids born and the other did not become pregnant. The recipient that received one frozen-thawed Bl-1 had one kid born. From three recipients receiving one embryo each, two became pregnant and gave a birth. One goat receiving two cryopreserved hatched blastocysts gave a birth to one kid.

\section{DISCUSSION}

The kidding rate obtained in this study after conventional transfer of embryos cryopreserved by slow freezing $(60.0 \%)$ was similar to that obtained with fresh embryos $(66.7 \%)$. The kidding rate for frozen-thawed embryos of the present study was slightly superior to results reported by Baril et al. (2000; 47\%) and Guignot et al. $(2006 ; 48 \%)$ for Alpine and Saanen, Holm et al. (1990; 53\%) for Angora and McKelvey and Bhattacharyya (1992; 53\%) for Cashmere goats after slow freezing with ethylene glycol. In addition, it is important to highlight in the present study that $45 \%(13 / 29)$ of frozen embryos were in early developmental stages (Mc and $\mathrm{Bi}$ ) and $27.6 \%(8 / 29)$ were of regular quality (Grade 3).

The likelihood of embryo survival and pregnancy development is directly related to embryo quality. The procedures of freezing and thawing cause injuries that could compromise the viability of the embryos, especially those previously classified as of poor quality (revised by Martemucci and D'Alessandro, 2013). For these reasons, over the years in animal assisted reproduction it has been stated that only embryos of grade 1 and 2 quality could undergo freezing without significant reduction of pregnancy rates, while regular and poor quality embryos should only be transferred as fresh (Phillips and Jahnke, 2016). However, results of the present study 
indicate that goat embryos of different morphological classification can be frozen/thawed and directly transferred, resulting in relatively good pregnancy rates. Embryos with grade lower than 2, often classified as not suitable for freezing and discarded, also resulted in pregnancies. This may represent additional kids born when using the technique described in present study.

Gall et al. (1993) compared in goat survival rates of early (morulae) and advanced (blastocysts) embryos using different freezing procedures. When they used $1.5 \mathrm{M}$ ethylene glycol in three steps for dehydration and rehydration, the percentage of kids born was 54.7 and $46.8 \%$ for morulae and blastocysts, respectively, after thawing and selecting embryos (better quality after thawing, respectively). However, in the reported study, considering the overall embryos thawed, the embryo survival rates were 34.5 and $35.0 \%$ for morulae and blastocysts, respectively. Considering that in the present study all embryos thawed were transferred, our results are encouraging.

Vitrification has been suggested as a viable and simpler method for goat embryo cryopreservation in substitution to traditional slow freezing technique. In this context, Gibbons et al. (2011) reported survival rates of $63.6 \%$ and $0.0 \%$ for embryos vitrified at blastocyst and morulae stages. Thus, results of the present study showed similar survival rate for blastocysts and appear to be more adequate to earlier embryonic stages when compared to vitrified embryos previously reported. In addition, in spite of the use of freezing machine, the one-step dehydration and rehydration and direct transfer appear to be more suitable than three-step method required to vitrification and other slow freezing reported techniques.

Besides the viability to cryopreserve grade 3 embryos, the present study also showed the possibility to cryopreserve hatched blastocysts. These findings could be important when working with low responding donors or with donors belonging to endangered breeds. In these cases, additional kids can be produced from embryos that are not usually cryopreserved (regular quality and hatched embryos).
Considering only grade 1 to 2 embryos, $61 \%$ of fresh (14/23) and $62 \%$ of frozen-thawed embryos $(13 / 21)$ resulted in kids born, demonstrating the efficiency of the procedures used to recover, handle, and cryopreserve the embryos, as well as recipient preparation and embryo transfer. As proposed by Pereira et al. (1998), cloprostenol was given to donors $16 \mathrm{~h}$ before embryo recovery to promote cervical dilation and allow cervical transposing for uterine flushing end embryo recovery. Although it certainly has altered hormonal status (decrease in plasma progesterone level), this expected change occurred in a short period (16h) until embryo recovery. Thus, based in kidding rate, it can be concluded that this period of hormonal disturbance was not deleterious to embryo health, cryopreservation and finally for embryo viability after transfer of both frozen-thawed and fresh embryos.

The whole technique described in the present study includes the use of $1.5 \mathrm{MEG}$ in a one-step dehydration and strategic position embryo / cryoprotectant column between two PBS 20\% FCS columns into pallet and it appeared to be adequate to immediate embryo thawing rehydration in a one-step system allowing direct transfer. Survival rate of the present study $(51.7 \%)$ was superior to similar previous reported study (20.7\%; Guignot et al. 2006) that used direct rehydration into the palled and direct transfer.

The present study combined the slow cooling rate and ethylene glycol at low concentration. Slow cooling rate allows an equilibrium freezing due to more adequate exchange of fluid between extra and intracellular spaces resulting in a safe freezing without osmotic effects and severe deformation of the cells (Mazur, 1990). This technique is accepted as a safe procedure because of the low toxicity of the cryoprotectant, especially of ethylene glycol, which is commonly used in low concentrations (Guignot et al., 2006), reducing toxic and osmotic damages associated with cryopreservation (Valojerdi et al., 2009). Thus, the combination of slow freezing and $1.5 \mathrm{M}$ EG based solution appear to be adequate to allow cryopreservation and direct embryo transfer in goats. 
Finally, the technique for embryo transfer involving sterile insulin with air inside and sterile tips to couple siring to straw and the straw to uterus appeared to be safe and easy to perform while avoid non-sterile instruments (i.e. straw) contact to the uterine horn.

\section{CONCLUSIONS}

The use of ethylene glycol and slow cooling rate was efficient for the cryopreservation of goat embryos, resulting in good embryo survival rate when directly transferred to recipient goats, even after the transfer of lower quality embryos (grade 3). This strategy may represent additional number of kids born from high genetic donor goats and perhaps for those in special conditions, as for poor responder donors or for endangered breeds.

\section{ACKNOWLEDGEMENTS}

The authors wish to thank FAPEMIG (CVZAPQ 01367-9 and CVZ PPM 00042-14) and CNPq 310166/2012-8) for financial support. JFF, FZB, JHMV and MEFO are fellows of the CNPq and JMGSF and RITPB of CAPES.

\section{REFERENCES}

AZIZ, M.A. Present status of the world goat populations and their productivity. Lohman Inf., v.45, p.42-52, 2010.

BARIL, G.; CASAMITJANA, P.; PERRIN, J. et al. Embryo production, freezing and transfer in Angora, Alpine and Saanen goats. Zuchthygiene, v.24, p.101, 1989.

BARIL, G.; LEBOEUF, B.; POUGNARD, J.L. et al. Embryo transfer after freezing with ethylene glycol from alpine and Saanen dairy goats. In: PROCEEDINGS OF THE INTERNATIONAL CONFERENCE ON GOATS, 7., 2000, Montesilvano. Proceedings... Montesilvano: [AEV], 2000. p.1030.

BILTON, R.J.; MOORE, N.W. In vitro culture, storage and transfer of goat embryos. Aust. J. Biol. Sci., v.29, p.125, 1976.

FACÓ O.; LÔBO R.N.B.; GOUVEIA A.M.G. et al. Breeding plan for commercial dairy goat production systems in southern Brazil. Small Ruminant Res., v.98, p.164-169, 2011.
FONSECA, J.F.; BRUSCHI, J.H.; ZAMBRINI, F.N. et al. Induction of synchronized estrus in dairy goats with different gonadotropins. Anim. Reprod., v.2, p.50-53, 2005.

FONSECA, J.F.; TORRES, C.A.A.; PINTO NETO, A. Criopreservação de embriões bovinos. Vet. Notícia, v.8, p.115-123, 2001.

FONSECA, J.F.; ZAMBRINI F.N.; ALVIM, G.P. et al. Embryo production and recovery in goats by nonsurgical transcervical technique. Small Ruminant Res., v.111, p.96-99, 2013.

GALL, F.; BARIL, G.; VALLET, J.C. et al. In vivo and in vitro survival of goat embryos after freezing with ethylene glycol or glycerol. Theriogenology, v.40, p.771-777, 1993.

GIBBONS, A.; CUETO, M.I.; PEREYRA BONNET, F. A simple vitrification technique for sheep and goat embryo cryopreservation. Small Ruminant Res., v.95, p.61-64, 2011.

GUIGNOT, F.; BOUTTIER, A.; BARIL, G. et al. Improved vitrification method allowing direct transfer of goat embryos. Theriogenology, v.66, p.1004-1011, 2006.

HOLM, P.; PETERSEN, B.A.; HEPBURN, J. et al. Transfer of Angora goat embryos imported into Denmark from New Zealand under quarantine conditions. Theriogenology, v.33, p.251, 1990.

JAUME, C.M.; BRUSCHI, J.H. Cabras sem limites. Jornal $O$ Estado de Minas, 26 out., p.67, 1990.

LÔBO, A.M.B.O.; LÔBO, R.N.B.; FACÓ, O. et al. Characterization of milk production and composition of four exotic goat breeds in Brazil. Small Ruminant Res., v.153, p.9-16, 2017.

MARTEMUCCI, G.; D’ALESSANDRO, A.G. Efficiency of $\mathrm{FSH} / \mathrm{LH}$ treatments for in vivo production of embryos and their cryopreservation by different methods in goats. Small Ruminant Res., v.114, p.264-271, 2013.

MAZUR, P. Equilibrium, quasi-equilibrium, and nonequilibrium freezing of mammalian embryos. Cell Biophys., v.17, p.53-92, 1990.

MCKELVEY, W.A.C.; BHATTACHARYYA, N.K. Embryo biotechnology in goats. Pre-conference proc., plenary papers and invited lectures. In: INTERNATIONAL CONFERENCE ON GOATS, 5., 1992, New Delhi. Proceedings... New Delhi: International Goat Association, 1992. p.51-70, 1992. 
PEREIRA, R.J.T.A.; SOHNREY, B.; HOLTZ, W. Nonsurgical embryo collectionin goats treated with prostaglandin F2-alpha and oxitocin. J. Anim. Sci., v.76, p.360-363, 1998.

PHILLIPS, P.E.; JAHNKE, M.M. Embryo transfer (techniques, donors, and recipients). Vet. Clin. Food Anim., v.32, p.365-385, 2016.

POLGE, C.; SMITH, A.U.; PARKES, A.S. Revival of spermatozoa after vitrification and dehydration at low temperatures. Nature, v.164, p.666, 1949.

PULS-KLEINGELD, M.; NOWSHARI, M.A.; HOLTZ, W. Cryopreservation of goat embryos by the one-step or three-step equilibration procedure. In: LOKESHWAR, R.R. (Ed.). Recent advanced in goat production. New Delhi: Nutan Printers, 1992.

RAO, V.H.; SARMAH, B.C.; ANSARI, M.R. et al. Survival of goat embryos after rapid freezing and thawing. Proc. World Conf. Anim. Prod. Japan, v.2, p.64, 1983.

RONG, R.; GUANGYA, W.; JUFEN, Q. et al. Simplified quick freezing of goat-embryos. Theriogenology, v.3, p.252, 1989.
STRINGFELLOW, D.A.; SEIDEL, S.M. Manual da sociedade internacional de transferência de embriões. 3.ed. [Uberlândia]: Sociedade Brasileira de Transferência de Embriões, 1999. 180p.

VALOJERDI, M.R.; EFTEKHARI-YAZDI, P.; KARIMIAN, L. et al. Vitrification versus slow freezing gives excellent survival, post warming embryo morphology and pregnancy outcomes for human cleaved embryos. J. Assist. Reprod. Genet., v.26, p.347-354, 2009.

WHITTINGHAM, D.G. Survival of mouse embryos after freezing and thawing. Nature, v.233, p.125-126, 1971.

WHITTINGHAM, D.G.; LEIBO, S.P.; MAZUR, P. Survival of mouse embryos frozen to $-196^{\circ} \mathrm{C}$ and $-269^{\circ} \mathrm{C}$. Science, v.178, p.411-441, 1972.

WILMUT, I. The effect of cooling rate, warming rate, cryoprotective agent and stage of development of survival of mouse embryos during freezing and thawing. Life Sci., v.11, p.1071-1079, 1972. 